\title{
Nigeria’s Bank of Agriculture: An Agenda for Organizational Renewal
}

\author{
Adetunji Adeniyi ${ }^{1}$ \\ ${ }^{1}$ Tunji Adeniyi and Associates Limited, Lagos, Nigeria \\ Correspondence: Adetunji Adeniyi, Tunji Adeniyi and Associates Limited, Lagos, Nigeria. www.tunjiadeniyi.io. Tel: \\ 234-(0)-805-700-0700. E-mail: tunjiadeniyi@icloud.com
}

Received: April 15, 2021

Accepted: April 24, 2021

Online Published: May 8, 2021

doi:10.5430/jbar.v10n1p41

URL: https://doi.org/10.5430/jbar.v10n1p41

\begin{abstract}
Bank of Agric (BoA) was establish as a special purpose specialized financial institution to provide agricultural loans to deserving customers as a way to promoting access to affordable credit facilities to segments of the Nigerian society that have little access to the services of conventional banks while accepting savings deposits from customers and encouraging banking habits at the grass-roots. However, the performance of the bank has been below expectation because it has not fulfilled purpose. In a country like Nigeria of N200 million population, where agriculture currently provides about 54 per cent of employment and the quest for economic resilience and sustainability is further driving diversification into agribusiness, improving access to agricultural credit, is imperative. It is against this background that the need to reposition the bank becomes necessary. It is recommended that the bank be partially privatised for access to increased / private capital, while its operations should be modernized and computerized to improve customer convenience and operational efficiency.
\end{abstract}

Keywords: Agricultural loans, banking, organizational renewal, agricultural finance

\section{Introduction}

Agriculture remains a major sector of the Nigerian economy, despite some structural transformation of the economy over the last few decades. Agriculture contributes about 54 per cent (down from about 70 per cent in the 1960s and 68 per cent in 1981) employment in 2014, and accounting for about 23 (down from about 70 in the 1960s) per cent of the gross domestic product (GDP) in 2014 (Adeniyi, 2019; Adetiloye, 2012). Potentially, the sector has far greater capacity, but for the militating factors, principal among which is lack of access to timely, affordable, and appropriate finance. This is compounded by the special nature of agriculture, the way we practice it in Nigeria and the risks and uncertainties associated with the two factors. Nigeria's agriculture is still largely rain-fed and dominated by old peasant farmers. Although commercial and technology-assisted agriculture will realize the latent potentials, this is yet to take off effectively (Olubiyo \& Hill, 2003).

The Bank of Agriculture (BoA) and its predecessors were set up to address this finance gap, as most orthodox commercial banks shy from lending to agriculture, despite its critical role in providing employment, industrial raw material, food security and export. The Bank of Agriculture is wholly owned by the Federal Government of Nigeria, 60 per cent by the Federal Ministry of Finance Incorporated and 40 per cent by the Central Bank of Nigeria (CBN). The Bank has become insolvent, with a negative shareholders' fund of about N65billion, down from the paid up capital of N34 billion as at 2019.

Incorporated as Nigerian Agricultural Bank (NAB) in 1973, the bank was renamed Nigerian Agricultural and Cooperative Bank in 1978, apparently to reflect the role cooperatives were to play in the development of the agricultural sector and the renewed focus of the bank. In 2000, it was consolidated with Peoples' Bank of Nigeria $(\mathrm{PBN})$. In the same consolidation exercise, it also assumed the risk assets of the Family Economic Advancement Programme (FEAP) of government to become Nigerian Agricultural Cooperatives and Rural Development Bank (NACRDB). I was, subsequently, renamed Bank of Agriculture (BoA) in 2010, and given a renewed mandate to provide affordable credit facilities to segments of the Nigerian society, who have little access to services of conventional banks, while accepting savings deposit from customers and encouraging banking habits at the grassroots.

Given the large population of the people in its target market - agriculture and agribusiness value chain - and their demography, the renewed mandate is laudable because of the intension of government to enhance financial inclusion 
and all-inclusive economic development in the process. Unfortunately, it is apparent that the bank has not excelled in this responsibility. Despite its current underperformance, the bank's potentials are enormous. It can revolutionize agricultural finance in Nigeria and set a role model standard for similar institutions across Africa and the world, if appropriately reorganized, recapitalized and rejuvenated.

\subsection{Justification for the Case Study}

The most recent recent economic recession in Nigeria, which revolved around the fall in the price of its mono-product (petroleum) export, calls for a diversification of the economy, principally, to agribusiness (FGN, 2017). The agriculture sector already employs about 52 per cent of the workforce, but contributing a less than commensurate 23 per cent to gross domestic product (GDP) (Adeniyi, 2019).

A most critical and persistent problem identified for this sub-optimal contribution of the agric sector to GDP is the peasant nature of their operations due to lack of access to appropriate credit, since the orthodox commercial banks shy away from underwriting agricultural credit risks. This made the Federal Government of Nigeria to establish the Bank of Agriculture (initially as Nigerian Agricultural Bank) as a special purpose intervention vehicle in 1973 (Adetiloye, 2012).

Unfortunately, too, the bank has not been able to serve its purpose effectively due to its own problems that this study seeks to identify and proffer solution to. If and when the identified problems are addressed, the bank will be able to support the agriculture sector to fulfil its expected role in a diversified and resilient economy of Nigeria.

\section{Literature Review}

\subsection{Importance of Agriculture Sector in Nigeria}

Agriculture is an important economic sector in Nigeria. It used to be the mainstay of the Nigerian economy prior to the discovery of petroleum in commercial quantities in the late 50s. Before then, agriculture accounted for more than 70 per cent of both employment and gross domestic product (GDP) (Adetiloye, 2012). As it is common, Nigerian caught the "Dutch Disease" and all the other sectors, including agriculture which up until 1981 provided 68 per cent of employment, food security, and raw material for industry were neglected (Adeniyi, 2019). After the initial oil boom, sets in a period of instability and diminishing fortunes in the oil economy. The declining oil economy has been aggravated by the clamor for environmental sustainability and the increasing preference for green energy, as against fossil fuels.

Consequently, the desire for economic stability and sustainability, food security and environmental sustainability is driving Nigeria to diversify its economy, particularly, into value-added agribusiness, lately (FGN, 2017; and, 2020).

\subsection{Problems of Agriculture in Nigeria}

Agriculture in Nigeria is faced with many problems. The sector is still largely undeveloped and characterised by peasant farm holdings and holders. Affordable, easy and guaranteed access to land, market, credit, technology and infrastructure are the major problems. Access to timely, affordable, and appropriate (in terms of tenor, repayment cycle, and agricultural credit insurance) constitute a critical factor (Adeniyi, 2019; Adetiloye, 2012).

The fiscal support for agriculture is very weak. Government spending on the sector is abysmally low at an average of about 2 per cent of annual national budget as against the 10 per cent recommended in the 2003 Maputo declaration, by African leaders, to which Nigeria was a signatory. Compounding the problem of low public investment in agriculture is the low credit extension to the sector and the poor implementation of the Agricultural Credit Guarantee Scheme (ACGS) (Adetiloye, 2012).

Risk and uncertainty are major limiting factors in lending to agriculture. Beyond risk, however, Olubiyo and Hill (2003) observed that the sector is dominated by small peasant farmers who lack access to capital and credit, thereby necessitating policy interventions. In 1969, for example, the Central Bank of Nigeria issued a monetary policy requiring banks to lend a fixed minimum proportion of their credit portfolio to agriculture. Any shortfall in this proportion was then taken by the Central Bank of Nigeria and passed on to the predecessors of BoA (after it came on board in 1973) for on-lending to agriculture. This policy was dropped with the liberalisation that accompanied the privatisation and commercialisation of the banking industry in the late 1980s.

\subsection{Agricultural Finance and Problems of Financing Agriculture in Nigeria}

The establishment of Nigerian Agricultural Bank (NAB) in 1973 came with a lot of promise for agricultural lending in Nigeria. Apparently, the reforms that were characterised by change of its names from NAB to NACB, NACRDB and, lately, to BoA were only cosmetic as it did not result in the Banks internal efficiency, or its effectiveness in 
serving its purpose.

Compared to similar institutions in similar economies, the loan recovery rate at BoA was less than 70 per cent, whereas in the other economies, between 95 and 99 recovery rates were achieved. In terms of its outreach, whereas, similar institutions else where we able to achieve as high as 99 per cent, the coverage of BoA is less than 20 per cent of Nigerian farmers. The Nigerian problem can be traced to the problems identified in the SWOT analysis: management incompetence, poor education and poor banking culture of the peasant farmers, staff (motivation, training and development) issues, ICT challenges and data integrity, the risk prone nature of rain-fed seasonal agriculture and its exposure to diseases and pests.

Table 1. Comparison of similar institutions across similar economies

\begin{tabular}{|c|c|c|c|c|c|c|c|}
\hline Institution & Country & $\begin{array}{l}\text { Year } \\
\text { Founded }\end{array}$ & Ownership & $\begin{array}{l}\text { Outreach } \\
(\%)\end{array}$ & $\begin{array}{l}\text { Recovery } \\
\text { Rate (\%) }\end{array}$ & ICT/MIS & $\begin{array}{l}\text { Source(s) } \\
\text { of Fund }\end{array}$ \\
\hline BAAC & Thailand & 1966 & Government & 98 & 95 & Robust & $\begin{array}{l}\text { Savings/ } \\
\text { Deposits }\end{array}$ \\
\hline $\begin{array}{l}\text { LAND } \\
\text { BANK }\end{array}$ & Philippines & 1963 & Government & $\begin{array}{l}\text { Not } \\
\text { Available }\end{array}$ & 75 & Robust & $\begin{array}{l}\text { Government/ } \\
\text { Deposits }\end{array}$ \\
\hline BRI-UD & Indonesia & 1895 & Government & 99 & 98 & Robust & Deposits \\
\hline GB & Bangladesh & 1976 & Semi-Government & 98 & 99 & Robust & $\begin{array}{l}\text { Savings/ } \\
\text { Deposits }\end{array}$ \\
\hline $\begin{array}{l}\text { BAN } \\
\text { RURAL }\end{array}$ & Guatemala & 1970 & Government & $\begin{array}{l}\text { Not } \\
\text { Available }\end{array}$ & 99 & Robust & $\begin{array}{l}\text { Donor/ } \\
\text { Savings/ } \\
\text { Deposits }\end{array}$ \\
\hline ACLEDA & Cambodia & 1993 & Semi-Government & $\begin{array}{l}\text { Not } \\
\text { Available }\end{array}$ & $\begin{array}{l}\text { Not } \\
\text { Available }\end{array}$ & Robust & $\begin{array}{l}\text { Savings/ } \\
\text { Deposits }\end{array}$ \\
\hline $\mathrm{BoA}$ & Nigeria & 1973 & Government & $<10$ & $<70$ & Pedestal & $\begin{array}{l}\text { Savings/ } \\
\text { Deposits/ } \\
\text { Government }\end{array}$ \\
\hline
\end{tabular}

Source: Adeniyi, A. 2014. Nigerian Bank of Agriculture - A Transformation Agenda.

The peculiar inherent risks in agricultural lending has also led to the establishment of many initiatives and schemes by government. The Agricultural Credit Guarantee Scheme Fund (ACGSF) was established in 1977 by the Central Bank of Nigeria to guarantee the reimbursement of commercial banks to the tune of 75 per cent of their exposure to agriculture, should there be loss due to default after realizing the security. The scheme did not achieve purpose due to poor implementation, the process of which was also compromised (Olubiyo \& Hill, 2003).

The Nigerian Agricultural Insurance Scheme (NAIS) was established in November, 1987 to provide agricultural risks insurance cover to Nigerian farmers. The Nigerian Agricultural Insurance Corporation NAIC (and its predecessor) was established with 100 per cent government ownership to implement the scheme because of the gap created by the conventional insurers who consider agriculture risks too risky to be unattractive. The scheme covers agricultural income, agricultural investments, performance guarantees, bid guarantees, and custom bonds (NAIC, 2021). The general consensus is that the scheme has not been effective (Ibitoye and Saliu, 2019; and, Epetimehin, 2010).

The Central Bank of Nigeria, apparently not satisfied with the quantum, tenor, and structure of credit going to agriculture, despite its subsidies, support and encouragement of the commercial banks and BoA, and in furtherance of its development objectives has been doing direct lending lately through its Anchor Borrowers' Programme.

\section{Methodology}

The issues preceding the establishment of the Bank of Agriculture (BoA) and its predecessors were reviewed. This 
was followed by a review of the historical corporate information relating to its establishment its establishment and performance. Similar institutions across similar economies of the world were, also, reviewed and compared with the establishment and performance of BoA.

A SWOT (Strength-Weaknesses-Opportunities-Threats) Analysis was carried out on BoA, particularly in comparison with world best practices in the various areas of operation, bearing in mind the peculiarities of the Nigerian situation and environment. This was to determine BoA's strategic options and intent, aimed at capitalizing on and emphasizing its strength in exploiting the opportunities in the Nigerian agricultural finance space, whilst minimizing its weaknesses and avoiding the environmental threats.

In order to fill-in any possible information gap that may exist in reviewing only dead corporate records of the institution, key informants, comprising key management staff, customers, and other important gender-balanced stakeholders, were interviewed.

The results of the interviews, analyses, strategic comparisons, and interviews were used to design a model of what an effective and efficient Bank of Agriculture (BoA) should be and do.

\section{Results and Discussions}

Table 2. Situation and SWOT analysis

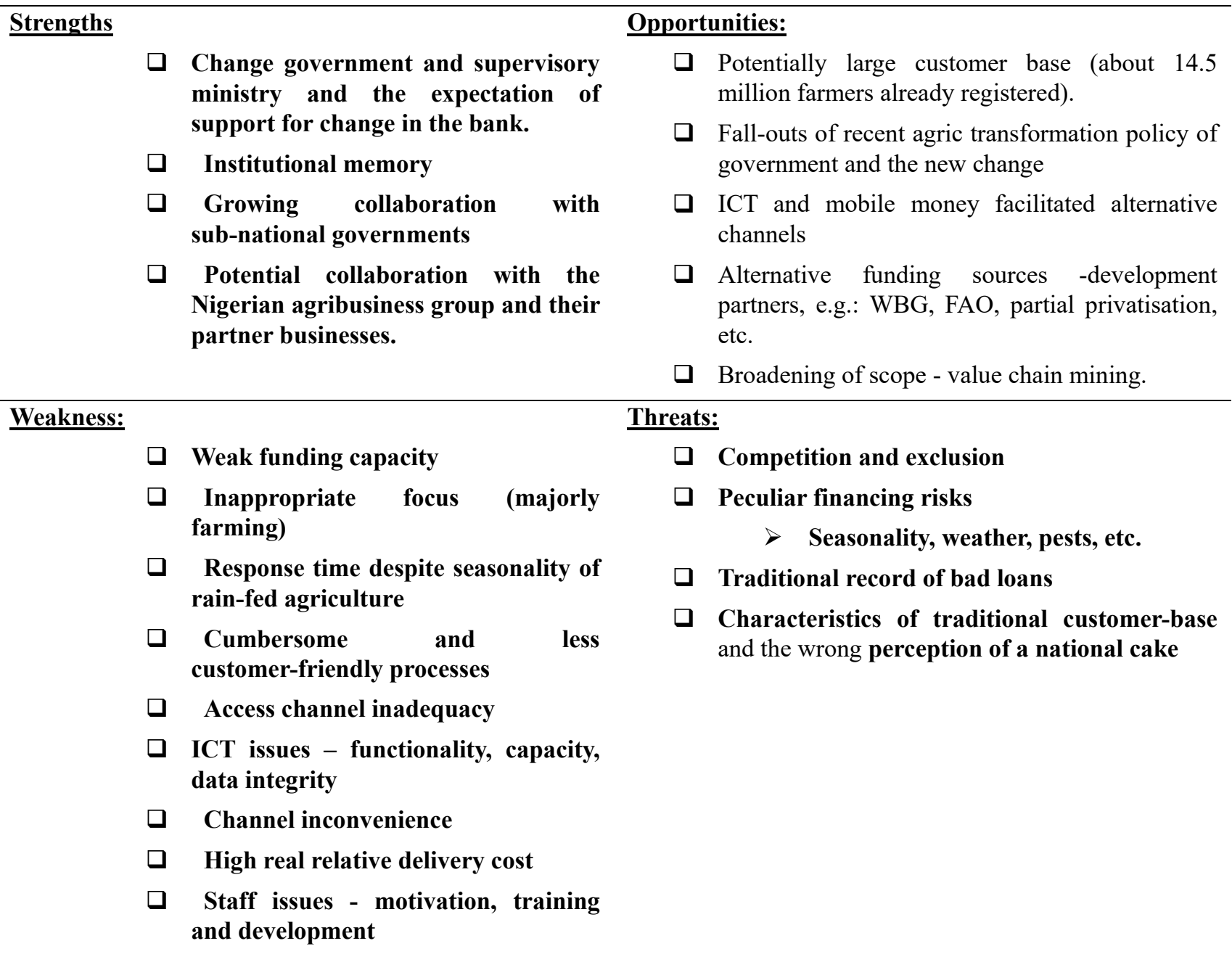

\subsection{Strengths}

Change government and supervisory ministry and the expectation of support for change in the bank: The current "Change Government" is full of promises to revolutionize agribusiness in the trajectory that the immediate 
past transformation regime of Dr Akinwumi Adesina, as the very first professional Minister of Agriculture and Rural Development, had started. The pronouncements of the new President and the new Minister of Agriculture and Rural Development suggest a continuation of the reforms in the Agricultural sector. The establishment of xxx (NIRSAL), the initiative to de-risk agricultural finance and the determination to reposition Bank of Agriculture (BoA) by the regime of Dr Akinwumi Adesina is a natural direction of policy continuity.

Institutional memory: Bank of Agriculture (BoA) has the institutional memory for lending to the agribusiness sector across the length and breadth of Nigeria. Such geo-ecological and demographic memories are a necessary resource in the ordinarily risky and uncertain agricultural lending landscape that Nigeria is.

Growing collaboration with sub-national governments: Lately, BoA has introduced a programme of collaboration with the sub-national governments as a way of gaining volume and sharing its risks through the development of commercially viable plantations, viable value-chains, and underwriting risks with the support of the sub-national governments.

Potential collaboration with the Nigerian agribusiness group and their partner businesses: There is also a growing collaboration with the Organized Private Sector (OPS) through the Nigerian Agribusiness Group, comprising of tested investors in large-scale agribusiness, as opposed to the high risk-prone peasant farmers that used to constitute only the target market of the bank. This realignment of target marketing is a good recipe for success.

\subsection{Weaknesses}

Weak funding capacity: BoA has a very narrow funding base. Although it was set up to attract deposits from both government and individuals, it has been spoon-fed in the past as it places almost exclusive reliance (more than 90 percent) on government for it funding. Avenues to attract primary deposit from the society and its customers are largely undeveloped or under developed, at the best.

Inappropriate focus (majorly farming): In the past, the Bank of Agriculture has been dealing majorly with peasant farmers. This segment of the market is largely uneducated and cannot easily adopt modern farming methods, and new technology. The dearth of extension workers has further compounded this problem. Besides, this segment lacks the equity capital to absorb operational shocks and attract external funding. Furthermore, they lack the management competences to ensure success, continuity and sustainability.

Response time despite seasonality of rain-fed agriculture: Nigerian agriculture is still largely rain-fed and weather-dependent. Unfortunately, the communication and approval channel within the bank is outdated, long and convoluted, leading to long credit approval turnaround and response time. Consequently, credit arrival is not in congruent with the time of need most times. Hence, this increases the rate and volume of misapplied / diverted loans, and hence bad loans. On the other hand, discerning and decent prospects would not approach BoA because they are sure the credit will not arrive on time.

Cumbersome and less customer-friendly processes: The approval process of BoA loan is opaque, cumbersome and not convenient to the customer.

Access channel inadequacy: BoA has inadequate number of branches. From about 120 branches to a population of 200 million the bank recently embarked on branch closures as a result of which some states now have only one or two branch. Without a robust electronic banking platform, convenient banking has become impossible.

ICT issues: The functionality of the current ICT infrastructure is suspect, particularly, in the areas of capacity, and data integrity.

Channel inconvenience: The banking channels are few and far between, meaning that farmers would have to abandon their farms to attend to banking transactions across long distances that do not guarantee their convenience.

High real relative delivery cost: The combination of all of the above is to increase the cost of procuring banking transactions from the Bank of Agriculture.

Staff issues: The bank is currently staffed with largely disgruntled staff. Staff morale, and motivation are low. Staff training and development have received only little attention, particularly on technology enabled banking. Furthermore, as a specialized and focused bank, one would have expected a high proportion of subject-matter staff. The opposite is the situation, as only one management staff of the first 20 senior staff has a background in Agricultural Economics. The professionals in the rank and file do not feel encouraged that they could reach the peak of their careers, as the top is politicised and filled with irrelevant professionals. 


\subsection{Opportunities}

Potentially large customer base: About 54 per cent of employed Nigerians are engaged in the agricultural value chains, and are, therefore, potential customers to the bank of Agriculture.

Fall-outs of recent agric transformation policy of government and the new change: The determination of successive governments to revolutionize agriculture as a vehicle to diversify the economy presents great potentials for Agricultural Banking.

ICT and mobile money facilitated alternative channels: The availability of avenues and technology for alternative channels mean the bank can rapidly ramp-up channel development to attract customers from the various geographical zones of the country.

Alternative funding sources: There are opportunities to diversify the funding base of the bank into development partners (e.g.: WBG, FAO, IFAD) partial privatisation, large customers base, etc.

Broadening of scope: The bank can broaden the scope of its business outside the traditional peasant farmer to large corporate commercial agribusinesses and by mining the associated value chains.

\subsection{Threats}

Competition and exclusion: The abdication of its expected role has made completion to creep into what would have been the almost exclusive business business space of the bank of Agriculture. Commercial banks have developed smart ways to attract funds pre-destined by government and Central Bank of Nigeria to agriculture, without necessarily serving the interest of the sector commensurately. Worst still, even the Central Bank of Nigeria often precludes BoA from participating in its special lending schemes / programmes to agriculture, e. g. the Commercial Agriculture Credit (CAC) programme. Lately the Central Bank Of Nigeria, 40 per cent owners of BoA, has been engaging in direct lending, e.g. the Anchor Borrowers Scheme, even when it has not paid up its share of equity in the struggling BoA.

Peculiar financing risks: Agribusiness is very risky compared with the other types of businesses, particularly, at the current peasant form, due to the problems of seasonality, vagaries of weather, pests, diseases, etc., requiring special underwriting skill.

Traditional record of bad loans: The bank has a bad history of bad loans, with a loan recovery rate of less than 70 per cent.

Characteristics of traditional customer-base and the wrong perception of a national cake: Up till now government has played too prominent role in the bank. Unfortunately, the customers have responded rather negatively, seeing loans emanating from that institution as a share of the National cake, which they usually refused to pay back. Besides, most of them are old, not educated and find it difficult to adopt improved farming methods and technology.

\subsection{Recommendations}

Arising from the outcome of the SWOT Analysis and the peer comparisons above, it is imperative that the Bank cannot continue along the present ownership and mode of operations.

Government $100 \%$ ownership does not confer any advantage. The called capital has not been paid up for several years, and the Bank is grossly undercapitalized. Appointment of management does not follow best practices, but seen as one of the avenues for providing "job-for-the-boys." Management is subject to as frequent unnecessary changes as are the Ministers of the Federal Ministry of Agriculture and Rural Development, the supervisory ministry. Consequently, the bank has not benefitted from the best possible professional management. In terms of operation, the Bank is denied participation by the Central Bank of Nigeria (CBN, its 40 per cent owner) in the government (60 per cent owner) and or CBN sponsored agricultural finance programmes and instead, set up parallel structures and arrangements to intervene in agricultural lending. The Commercial Agriculture Credit (CAC, implemented through commercial banks) and the Anchor Borrowers Programme (implemented through the Central Bank's Development Finance Department) are key examples, among others. This is compounded by the fact that its own loans and advances are frequently uncollectable because they are seen as government largesse or the farmers' share of the "national cake." As a consequence, the only impact of the overbearing influence of government ownership is negative.

The current internal set-up and capacity of the Bank do not also support the expectations from a Bank that will revolutionize agribusiness finance effectively and efficiently in an economy of 200 million people to feed, where 
about 54 per cent of the workforce is directly employed in agriculture.

The Bank needs to strategize its business model and appropriately retool - recapitalize, computerize, re-engineer its processes, train and re-orientate its staff, expand its scope of operations, develop and deploy new products to delight its customers, and collect its loans and advances.

In this regard, the Bank should transform and rejuvenate. The change strategy vision should be: to achieve world best practice (role model) in agricultural financing.

The change strategy mission should be: we shall use the best people to promote and deliver prompt and perfect-fit financial products to agriculturists and agribusinesses conveniently in places of their businesses through reengineered processes at the right prices ( 8 "P" s).

The strategic intent should include the following:

Partial privatisation with control in the private sector, with the strategy to expand and enhance governance scope, expand funding scope, expand management scope, drive management performance, enhance staff development, enhance product development capacity, enhance process development, enhance ICT adoption and customer service;

Expand focus beyond farming finance to agribusiness finance;

Adopt value chain financing, and stimulate investment in missing links in strategic value chains and financing of those link (e.g. processing and marketing infrastructure, egg powder, etc.);

Mitigate traditional underwriting risks in agricultural finance by adopting NIRSAL fully, collaborating with other risk management stakeholders, adopt alternative risk management approaches (e.g. targeting lending to irrigated clusters, processing clusters, cooperatives, out-grower schemes);

Overhaul and re-engineer loan underwriting and delivery process to achieve prompt and timely loan access by deserving customers;

Increase and improve delivery channels to facilitate faster, convenient, and cost effective credit access, e.g. use of mobile money;

Develop and deploy appropriate loan products in terms of structure, tenor, amount, moratorium, pricing, etc.

Introduction and implementation of marketing and financial extension services;

Adoption of cutting-edge technology to serve the people;

Obtain mobile money license and integrate people-technology-service;

Well-trained people will use state-of-the-art-technology to provide service to technology-enabled customers;

Effective collaboration with the nigeria agribusiness group, and similar stakeholders in share ownership, loan structuring, cross-guarantees, etc.;

Designing and implementation of an effective loan structuring, disbursement, monitoring, collection, and recovery process.;

Enhancement of collaboration with sub-national governments;

Facilitation of the adoption of best practices in crop and animal husbandry, and in soil management; among others.

This strategic re-direction should be accomplished through a very well-structured all-inclusive implementation process in which the board, management, staff and all other stakeholders are involved, along the structure suggested in Figure 1 below. The process should involve a two-way all-engaging feedback, comprising data collection, data analysis, options identification, options review, results optimization, decision making, implementation, and evaluation as indicated in in Figure 2. 


\section{CHANGE IMPLEMETATION}

IMPLEMENTATIONSTRUCTURE

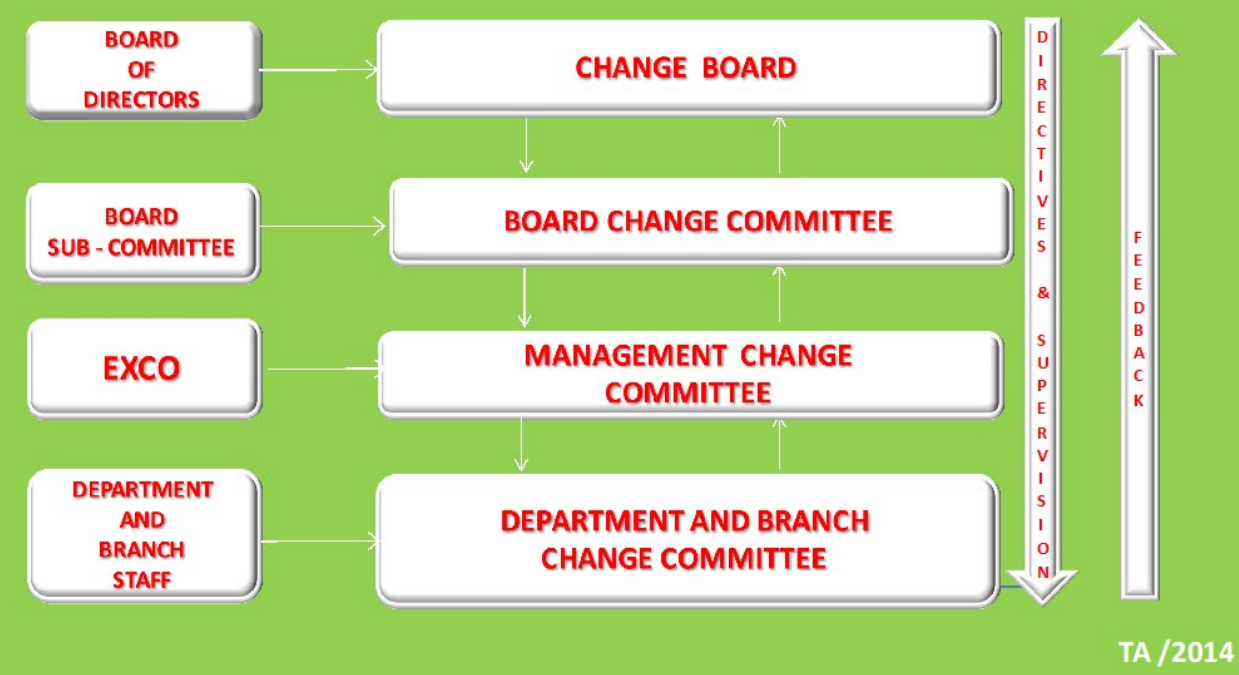

Figure 1. Change Implementation Organisation Structure

Source: Adeniyi, A. 2014. Nigerian Bank of Agriculture - A Transformation Agenda.

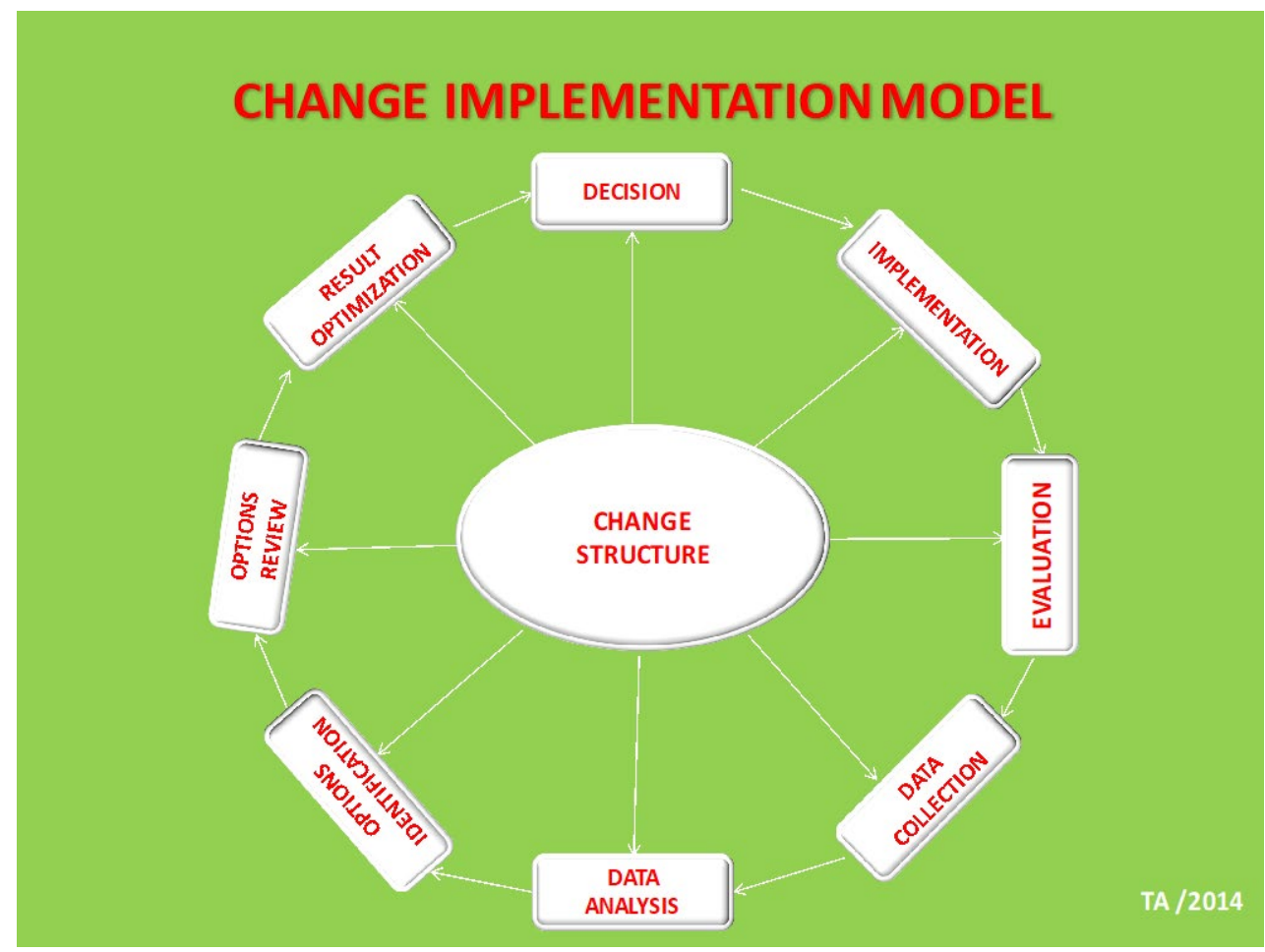

Figure 2. Change implementation Model

Source: Adeniyi, A. 2014. Nigerian Bank of Agriculture - A Transformation Agenda. 
The following change implementation action plan and implementation schedule are recommended: buy-in of all stakeholders; set-up of structures; establishment of processes; detailed action planning; execution of plans; results; and evaluation.

\subsection{Managerial and Theoretical Implications}

It is recommended that government should divest controlling shares of not less than 60 per cent to agricultural trade groups, cooperatives, and professionals. This will bring on board professional management and good potential customers that are committed to the success, strength and sustainability of the bank.

Management control and decision making will be in the hands of competent professionals. Furthermore, there will be improved access to adequate capital, a key factor in credit risk underwriting. There will be sound and timely credit risk underwriting decisions, thereby ensuring good quality and performing loan assets. In turn, these will combine to improve earnings capacity and quality. Performing assets and ownership patronage support will improve deposit and liquidity, all of which are ingredients for a strong and resilient bank. Furthermore, the dilution of government interest to minority ownership will remove injurious politics and red tape. Decision making speed will improve. The bank will become more responsive to customers, and innovations will thrive.

\section{Conclusions}

The Bank of Agriculture is expected to play an increasingly important role against the background of previous gross under-performance. To keep up with this expectation, it will need to transform in ownership, management, human capital, organization, scope of operation, processes, and resources. However, these cannot happen without the buy-in and support of its current owners.

With the required government (ownership) support and open-mindedness to to partial privatization, reforms and modernization, the Bank will achieve good and sustainable financial performance; and, good socio-economic behaviour, through rapid, sustainable and inclusive growth, wealth and job creation, food security (the beginning of true independence and national self-respect) diversified and stable economy, foreign exchange earnings through increased export, foreign exchange conservation through import substitution agric-led industrialization, inexpensive local raw material for industry, and increased FDIs.

\section{References}

Adeniyi, A. (2014). Nigerian Bank of Agriculture - A Transformation Agenda. An unpublished proposal submitted to the Minister of Agriculture and Rural Development.

Adeniyi, A. (2014). Nigerian Bank of Agriculture - An Agenda for Change. An unpublished proposal submitted to the Consultant to the Minister of Agriculture.

Adeniyi, A. (2018). Nigerian Bank of Agriculture - An Agenda for Change. An unpublished proposal submitted to the Bureau Public Enterprises, Nigeria. (BPE).

Adeniyi, A. (2018). Nigerian Bank of Agriculture - An Agenda for Change. An unpublished proposal submitted to the Director of Operation, Bank of Agriculture, Nigeria.

Adetiloye, K. A. (2012). Agricultural Financing in Nigeria: An Assessment of the Agricultural Credit Guarantee Scheme Fund (ACGSF) For Food Security in Nigeria (1978-2006). $J$ Economics, 3(1), 39-48. https://doi.org/10.1080/09765239.2012.11884951

Agbota, S. (2017). How N40bn non-performing loans crippled Bank of Agriculture. The Sun News July 21.

Bank of Agriculture Website. Retrieved from www.boanig.com

CBN ACGSF. Retrieved from www.cbn.gov.ng/devfin/acgsf

CBN. (2007). Statistical Bulletin, Abuja: CBN Publications

CBN. (2003). Agricultural Development: Issues of Sustainability. In: O. J. Nannna, S. O. Alade, \& E. O. Odoko (Eds.), Cotemporary Economic Policy Issues in Nigeria (pp. 185-222). Abuja: CBN Publications.

CBN. (2000). The Changing Structure of the Nigerian Economy and Implications for Development. Research Department. Abuja: Central Bank of Nigerian Publications.

Epetimehin, F. (2010). Agricultural Insurance in Nigeria and its Economic Impact. SSRN Electronic Journal. https://doi.org/10.2139/ssrn.1602926

Eze, C. C., Lemchi, J. I., Ugochukwu, A. I., Eze, V .C., Awulonu, C. A. O., \& Okon, A. X. (2010). Agricultural 
financing policies and rural development in nigeria. The 84th Annual Conference of the Agricultural Economics Society, Edinburgh 29th to 31st March.

Ibitoye, S. J., \& Saliu, O. J. (2019). An Evaluation of the Performance of Nigeria Agricultural Insurance Scheme in Kogi State, Nigeria. Asian Journal of Agricultural Extension, Economics \& Sociology, 33(2), 1-9. https://doi.org/10.9734/ajaees/2019/v33i230174

Manyong, V. M, Ikpi A., Olayemi, J. K Yusuf, S. A., Omonona R, \& Idachaba, F. S. (2003). Agriculture in Nigeria: Identifying Opportunities for Increased Commercialization and Investment. International Institute Tropical Agriculture USAID-Nigeria.

Morgues, T., Morris, M., Freinkman, L., Adubi, A., \& Ehui, S. (2008). Agricultural Public Spending in Nigeria. IFPRI discussion paper, page 108.

NIRSAL: Building Nigeria's Agribusiness Niche. Retrieved from https://www.nirsal.com.

Okumadewa, F. (1997). Poverty and Income in Nigeria - Measurements and Strategies for Reform Paper presented at the Vision 2010 Workshop. Abuja, April 14.

Okunneye, P. A. (2002). Policies and Strategies for Sustainable Food Security: A draft of Chapter 9 in the UNDP Nigeria Book titled Food Security in Nigeria presented at Agura Hotel. Abuja December 10-13.

Olubiyo, S. O., \& Hill, G. P. (2003). Beyond the Risk Factor: Bank Lending to Small-scale Peasant Farmers in Nigeria. African Review of Money Finance and Banking. Retrieved from https://www.jstor.org/stable/i23026308

Phillip, D. O. A. (1988). An empirical Preview of the Proposed Agricultural Insurance Scheme in Nigeria. African Review of Money Finance and Banking, No. 1 (pp. 5-15). Giordano Dell-Amore Foundation. Retrieved from https://www.jstor.org/stable/44944816

\section{Copyrights}

Copyright for this article is retained by the author(s), with first publication rights granted to the journal.

This is an open-access article distributed under the terms and conditions of the Creative Commons Attribution license (http://creativecommons.org/licenses/by/4.0/). 